\title{
IMPROVING STUDENTS' READING COMPREHENSION THROUGH COOPERATIVE SCRIPT AT SMP NEGERI 21 MEDAN
}

\author{
Novi Indah Yanta Br PeranginAngin, Linus Rumapea, Fiber Yun A. Ginting \\ Catholic University of Saint Thomas \\ Email : fiber_ginting@ust.ac.id
}

\begin{abstract}
This study is intended to answer the problem in what way does the cooperative script improvement of students' Reading Comprehension to the Eighth Grade Students' of SMP Negeri Medan Jaya in the academic year 2016/2017. This study is classroom action research. The tools of data collection used observation, interview and test. On the first cycle the researcher used cooperative script to improve the students' ability in comprehending on information of descriptive text about animal. The result of this research showed that the students ability in comprehending a descriptive text improved after applied the cooperative script. With this activity, students had more practice in reading. Besides, during the reading process students were active in asked and answered questions, this method also guide students to summarize the information of the passage. Consequently, the method successfully improved the students' ability in reading comprehension of descriptive text.
\end{abstract}

Keywords: reading comprehension, descriptive text, and cooperative script

\section{INTRODUCTION}

Reading is one of the four basic skills in learning a language besides listening, speaking, and writing. Reading is one of important skills in learning English which should be mastered by the students besides other skills. Reading is the ability to draw meaning from the printed page and interpret the information appropriately. Reading can be thought as a way to draw information from a text and to form an interpretation of that information.

Reading is the necessity for students if they want to expand their knowledge because most scientific books and knowledge are written in English. The students can adds their knowledge by reading books, articles, magazines, journals. With reading, the students know that information is important. They can share information from what they have read to the others. Through reading, they can get new ideas, obtain needed information, seek support for their ideas, complete their assignments and broaden their interest.

According to Grabe (2002:19) states that Reading is also a comprehending process. Reading is the process of comprehending text, it needs the student's ability in understanding the meaning of the text they are reading. Hyun (in Al, 2012:140) explains

Reading comprehension is a process that requires how to decode through the development of an extensive repertoire of sight words, learning the 
meanings of vocabulary words encountered in the texts, and learning how to abstract meaning from text. It represents how well readers understand literal comprehension which concentrates on explicit meaning and inferential comprehension which concentrates on implicit meaning in the reading text.

From the definitions above, reading comprehension is the process of comprehending the text which concentrates on explicit meaning and on implicit meaning in the reading text.

I find some students learn how to read and comprehend what they read quite well, but there are many students who have difficulty in learning how to read and comprehend what they have read. The problems are fluency, vocabulary and comprehension. The students are able to read the text, but they do not understand what the text is about, because the students still have lack of vocabulary. Then, the students still have difficulties in finding factual information from the text such as finding the meaning of words, main idea. When the teacher reads text, the students just listen and repeat what the teachers has read, but they do not understand what the information in reading text because the text is too long for the students and the text is not familiar with the students.

These phenomena invite me to find a method in order to solve the problems. At this present, there are many methods to teach reading comprehension. An appropriate method for teaching English language is very important because appropriate method determines the result of teaching reading comprehension. Cooperative script is learning method that make students work in pairs. According to Suprijono (2012:126-127) states "cooperative script is a study method where students works with their partner and they take turns verbally to summary the parts of material which are studied".

I am interested in applying Cooperative Script Method because this method is the simplest method and help students in heterogenous classes to motivate each other to develop learning concepts and ultimately to experience meaningful learning in a conductive learning environment. Through the Cooperative Script Method, the students are expected to have wonderful benefits for having relationship among their classmates to them, work together to improve their reading comprehension skill and increase their involvement in classroom activities. In this method, students work together in groups.

Based on the background above, I am interested in conducting a research entitled 'Improving Students' Reading Comprehension Trough Cooperative Script Method" at the Second Year Students of SMP Negeri 21 Medan Class VIII-2 in Academic Year of 2016/2017.

\section{REVIEW OF LITERATURE}

\subsection{The Definition of Reading}

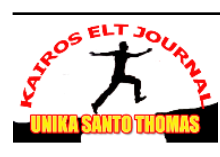


Reading is one of the most important skills because students not only read the text clearly, but they are also able to comprehend it. They must be able to understand what they are reading. Reading is considered as an active process where the readers utilize their cognitive and mental capacities to figure out the internal meaning of the text. Therefore, in this process, the readers should be provided with instructional opportunities that allow them to successfully derive the meaning intended by me. Nunan (2003:68) states that reading is a fluent process of readers combining information from a text and their own background knowledge to build meaning. The goal of reading is comprehension. Without their own background knowledge, the students will get difficulties to comprehend the text which they will read. With strengthened reading skills, learners will make greater progress and development in all other areas of learning.

Nunan (2003:69) states Reading is an essential skill for learners of English as a second language. For most of these learners it is the most important skill to master in order to ensure success not only in learning English, but also in learning in any content class where reading in English is required.

\subsection{Types of Reading}

Brown (2003:189) explains the types of reading. In the case of reading, variety of performance is derived more from the multiplicity of types of the text than from the variety of over types of performance. Nevertheless, several types of reading performance are typically identified as follow:

\section{a. Perceptive}

Perceptive reading tasks involve attending to the components of larger stretches of discourse: letters, words, punctuation, and other graphemic symbols.

b. Selective

This category is largely and artifact of assessment formats. In order to ascertain one's reading recognition of lexical, grammatical, or discourse features of language within a very short stretch of language, certain typical tasks are used: picture-cued tasks, matching, true/false, multiple choice, etc.

c. Interactive

Included among interactive reading types are stretches of language of several paragraphs to one page or more in which the reader must, in a psycholinguis tic sense, interact with the text. That is, reading is a process of negotiating meaning; the reader brings to the text a set of schemata for understanding it, and intake is the product of that interaction. Typical genres that lend themselves to interactive reading are anecdotes, short narratives and descriptions.

d. Extensive

Extensive reading, as discussed in this book, applies to texts of more than a page, up to and including professional articles, essays, technical reports, short stories, and books.

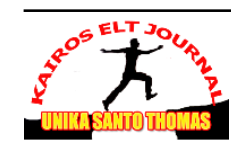




\subsection{Reading Comprehension}

Reading comprehension is the process of understanding and constructing meaning from a piece of text. Reading are necessary when students want to further their study, especially at the secondary level. They need to read for acquiring knowledge and learning new information. Reading with comprehension means understanding what has been read. Hyun (in Al, 2012:140) explains:

Reading comprehension is measured by three types of recall scores: recall scores for common ideas, main ideas, and non-main ideas of a text. Reading comprehension usually refers to the amount of understanding readers have when they read the text. That is, it represents how well readers understand the implicit and explicit meaning of the contents of the text they read.

From the definition about, reading comprehension refers to the amount of understanding what readers have when they read the text.

Comprehension in which a student reads can provide clues to his reading strength and instructional needs. Even the responses that children make on workbook pages can provide important diagnostic clues. Undoubtedly, one of the children reads a paragraph or two paragraph from basal reader, social studies or science text, or from a trade book. Comprehension tasks for silent reading can als o focus on important facets of critical reading.

\subsubsection{Levels of Reading Comprehension}

According to Burns (1984:177) there are four levels of reading comprehension. There are Literal Comprehension, Interpretative Comprehension, Critical Comprehension and Creative Comprehension.

\section{a. Literal Comprehension}

Literal comprehension involves the acquiring information that was directly stated in the text. The basic of literal comprehension was recognizing main idea, detailed cause effect, and sequence. It also perquisites for the higher - level understanding. Mastering the basic of literal comprehension can be done through understanding of vocabulary, sentence, meaning, and paragraph meaning.

b. Interpretative Comprehension

Interpretative comprehension involves reading between the lines or making inference. It is the ability of the readers to extract the ideas and the information that is not directly stated in the textbook material, using prior or background knowledge. Within this level, reader may make generalizations, determine cause and effect, identify motives, find relationship, predict endings, and make comparison.

\section{c. Critical Comprehension}

Critical comprehension involves evaluating written material, comprehension the material and drawing conclusions about the accurately, appropriateness timeless. Critical comprehension refers to the ability to make judgment about ideas and information a writer offers. The critic readers will measure the information 
from one sources with the other sources based on the standards apply after they can draw the conclusion.

\section{d. Creative Comprehension}

Creative comprehension includes creating new ideas from what was learned based on their experience of life and their opinion on issues relevant to the text. It requires readers to think as they read, just as critical reading, and it requires them to use their imaginations

\subsubsection{Assessment for Reading Comprehension}

Brown (2004:4) state that Assessment is popular and sometimes misunderstood term in current educational practice. Assessment, on the other hand, is ongoing process that encompasses a much wider domain. Whenever a student responds to a question, offer a comment, or tries out a new word or structure, teacher subconsciously makes an assessment.

According to Brown (2004: 189) there are some tasks for reading assessment task: perceptive, selective, interactive, and extensive. The task is used in order to assess reading in this research is selective. Selective is largely an artifact of assessment formats. In order to ascertain one's reading recognition of lexical, grammatical, or discourse feature of language within a very short stretch of language, certain typical task are used: picture-cued tasks, matching, true/false, multiple choice.

Based on the explanation above, I choose multiple choices test to measure students' achievement in reading comprehension. I realize that multiple choice test are the most widely and highly regarded among the selection type of items for test development. Brown (2004: 191) states "multiple choice formats are practical reliable and they give the possibility of an easy and consistent process of scoring and grading".

\subsubsection{The Purposes of Reading}

Before reading a text, the readers must determine their reading purposes.

According to Grabe (2002:12) there are some purposes of reading there are:

a. Reading to search for simple information and reading to skim

It is common reading ability, here the reader scan the text to find on a specific word. Meanwhile, reading to skim is the strategy to form the general idea using basic reading comprehension and guesses the important point.

b. Reading to learn from text

It happens in academic and professional context, it also requires remembering the main idea and supporting idea, making a relation with the reader's knowledge. This activity could bring stronger inference because it helps to remember information.

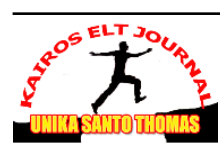


c. Reading to integrate information, write, and critique text

This skill needs critical evaluation where the reader integrate and decide the information that she/he wants. Then, it involves abilities such as composing, selecting, and making critique from the material.

d. Reading for general comprehension

It can be done by fluent readers very fast and automatically in the processing word, and effective coordination in many process of the text.

\subsection{Cooperative Script Method}

Cooperative script is a method of learning where students work in pairs and take turns verbally and explains the parts of the material in the study. A study of this cooperative script method has consistently found that students who study this way learn and retain far more than students who summarize on their own or who simply read the material. It is interesting that while both participants in the cooperative pairs gain from the activity, the larger gains are seen in the sections that students teach to their partners rather than in those for which they serve as listeners.

\subsubsection{The Advantages of Cooperative Script Method}

I use cooperative script in teaching learning comprehending. Cooperative script is learning methods that make students work in pairs. According to Najib in Nurul (2015:3) there are some advantages of cooperative script:

a. to make students to be active,

b. to make students can interact and care with the other,

c. to help students to understand new material,

d. teacher gave brainstorming through pieces of text and the text, students made a group consist two students in group, teacher gave pieces of text from one text divided into two parts, students read and comprehend the text, students identify generic structure, language feature, main idea, and supporting detail, each students made summarize include the generic structure, language feature, main idea, and supporting detail, students took roles as speaker and listener, the students decided who first serve as a speaker and who as a listener, students as a speaker: read the summary as completed as possible in include generic structure; language feature; main idea and supporting details, students as a listener: listener, correct and help remember about a summarize in script.

\subsubsection{The Steps of Cooperative Script}

According to Suprijono (2012: 126-127) Cooperative Script Method have steps as follows:

a. A teacher asks students to work with their partner.

b. A teacher gives discourse to each student to be read by them and make summary.

c. A teacher and student decide who will be the first to be as a speaker and a listener.

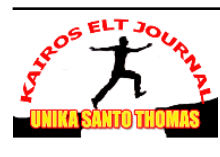


d. The speaker reads his summary completely with including main ideas in his summary. While the listener: corrects/shows main ideas which is less complete, and helps to remember main ideas with connecting before material or with the other material.

e. To change character, from the beginning as a speaker and he's changed to be a listener and viceversa.

f. Students and teachers' summary.

\subsection{Genres of the Text}

According to Gerot (1994:190) genre can be defined as a culturally specific text-types which results from using language (reading or spoken) to help accomplish something.

According to Gerot (1994:190-219) there are thirteen genres of the text namely:

a. Spoof : The social function is to retell an event with a humorous twist.

b. Recount : The social function is to retell events for the purpose of informing or entertaining.

c. Narrative : The social function is to amuse, entertain, and to deal with actual or vicarious experience in different ways; Narratives deal with problematic events which lead to a crisis or turning point of some kind, which in turn finds a resolution.

d. Procedure : The social function is to describe how something is accomplished through a sequence of action or steps.

e. Anecdote : The social function is to share with others an account of unusual or amusing incident.

f. Hortatory : The social function is to persuade the reader or listener that something should or should not be the case.

g. Explanation: The social function is to explain the processes involved in the information of working of natural or socio cultural phenomena.

h. Description : The social function is to describe how something is accomplished through a sequence of action or steps.

i. Discussion : The social function is to present(at least) two points of view about an issue.

j. Analytical : The social fuction is to persuade the reader or listener something is the case.

k. News item : The social function is to inform readers, listener, or viewers about events of the day which are considered news worthy or important.

1. Reports : The social function is to describe the way thing are with reference to a range of natural, man-mode and social phenomena in our environment.

$\mathrm{m}$. Reviews : The social function is to critique an art work or event for a public audience 


\subsection{Descriptive Text}

Descriptive text has a purpose to describe an object or a person that I am interested in. The generic structure of the descriptive text is different from other texts. There are two main components in the generic structure of descriptive text. They are identification and description.

Gerot (1994:208) state that descriptive text is to describe a particular person, place or thing. Which has the social function to describe the real thing; it can be person animal, lace, build and so forth. Thus, in writing a descriptive text the writers should know well what they want to describe.

1. Generic Structure of Narrative Text

The generic structures of narrative text are:

a. Identification : identifies phenomenon to be described

b. Description : describes parts, qualities, characteristics.

2. Language feature of Descriptive Text

Dominant language Features are

a. Focus on specific participants

b. Use of attributive and identifying processes

\subsection{Previous Researches}

Several researches have been conducted in relation to this study about improving students' reading comprehension through cooperative script method. The first research has been conducted by Nurul (2015). She conducted her research entitled 'Improving Students' Ability in Comprehending a Descriptive Text Trough Cooperative Script at the eleventh grade students of SMKS Pembangunan Rasau Jaya in the Academic year 2014/2015". The result showed that this method can improve the students reading comprehension, and it was effective. It can be seen from the score of pre-test 49,81 and post-test 75,58.

The second research has been conducted by Wulandari (2012) at the eighth grade of SMP PGRI Slahung Ponogoro in Academic Year 2011/2012 with the title "Improving Students Reading Comprehension in Descriptive Text Through Cooperative Script Method". The result showed that this method can improve the students' reading comprehension, and it was effective. It can be seen from score of pre-test 63.75 and post-test 76,24 .

Therefore I want to apply the same method to teach reading comprehension to eighth grade students of SMP Negeri 21 Medan in Academic year 2016/2017.

\section{RESEARCH METHODOLOGY}

\subsection{Research Design}

The kind of this study is classroom action research which using Cooperative Script Method in teaching reading class. Classroom action research is conducted by educational practitioners, with the goal of improving the particular institution at

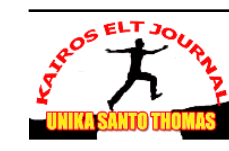


which they work. Action research is conducted by teachers and principals with students in that school as participants. Action research has as its focus the improvement of the organization in which the research is being conducted. It means the teacher can use classroom action research as a method to improve their skill (Vanderstoep, 2009:9)

It is needed to make clear the definition of classroom action research, Ferrance (2000:1) states that classroom Action Research is a process in which participants examine their own educational practice systematically and carefully, using the method of research. Through the classroom action research, the teacher will know the problem that students face in learning when the teacher is give acting to the student and evaluate their achievement in learning. It is also like a procedure to evaluate the successful of teaching learning process.

\subsection{The Place and Time of the Research}

The study would be conducted at SMPN 21 Medan which is located in Simalingkar. I choose this school because there never been other researchers who conducted the study with the same variable as the writer conducts. This study will be conducted at the beginning of the new semester in September 2016.

\subsection{The Subject of the Research}

The subject of this study was the second year students of SMP Negeri 21 Medan. There are five classes of the second year students. However, I took only one class as the subject of the study. They were class VIII 1, VIII 2, VIII 3, VIII 4, AND VIII 5. In this research, I choose VIII 2. This consists of 38 students, 17 males and 21 females.

\subsection{Technique for Collecting Data}

In this classroom action research, the writer collects the data using qualitative and quantitative method. The techniques of collecting the data consist of three types, namely observation, interview, and test.

\section{Observation}

In this study, I would observe teaching learning process before I am going to teach, this observation aims to get information about teaching learning process and students' reading comprehension.

2. Interview

I interview the teacher to obtain the information. It also aims to know the problems of the students in reading comprehension. Beside of that, I also interviews the student to know what students' complaining in reading class and I would ask the students to share their opinion, experience in teaching learning process.

3. Test

I would conduct the pre-test in reading class, it aims to know students' achievement in reading and I also would conduct the post-test with the same test as

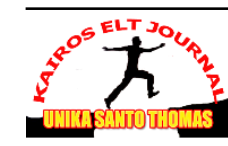


pre-test, it aims to know how students' achievement in reading after the Cooperative Script Method is applied. The test is multiple choice questions that contain 20 items. The instruments of collecting data are multiple choices taken from English book of the second grade of SMP Negeri 21 Medan and web pages. I choose the multiple choices because it is not only to test the students' grammar but also to encourage the students to think critically.

\subsection{The Procedure of Research}

The procedures of classroom action research include pre-research and classroom action research by Tampubolon (2014: 29). The procedures of the study were classified as follows:

\subsubsection{Pre-Research}

The pre-research was early reflecting before the Classroom Action Research, the activities of the pre-research as follows:

a. I collected the data of the school such as the location of the school, class, and curriculum.

b. I arranged the instrument for the Pretest. It was in multiple choices consisted of 20 items about descriptive text material.

c. I observed the English teaching learning process, it intended to obtain the information as a data. Then, I interviewed English teacher to obtain the information about reading class. It also needed to get the students' opinion and experience in reading class.

d. The Pretest was conducted in reading class with descriptive text material. The test was taken from website, it aimed to know students' achievement in reading.

e. The data of the school and Pretest were collected and analyzed after analyzing the data. The results of data were used for planning of teaching learning process in Cycle 1, then analyzing the result.

\subsubsection{Classroom Action Research}

The classroom action research consists of four steps in one cycle. These steps are the plan, the action, the observation, and the reflection.

In this research, the writer uses Design Classroom Action Research (CAR) model Kemmis \& McTaggart (2007:51) 


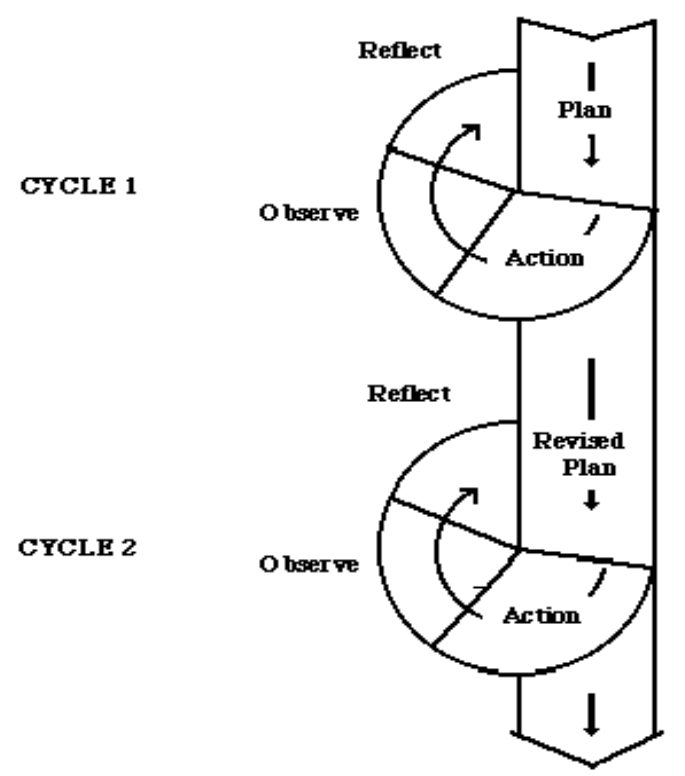

Fig 2. Model Kemmis \& McTaggart

\subsubsection{The Descriptive of Cycle I}

\section{a. Planning}

In order to succeed in this research, I prepared several planning before the acting, they were: a. Lesson plan, it was very it was very important since it refered as compulsory tool in teaching learning process, I made lesson plan for Cycle 1, it consisted of standard of competence, basic of competence, and the material of instruction, b. I also prepared the handbook, c. Then, I prepared the instrument such as the observation sheet in observing the teaching learning process and the test to measure students' reading comprehension.

\section{b. Acting}

The study was conducted based on the planning stated previously for applying the Cooperative Script Method in teaching reading comprehension, namely: a. I greeted the students and asked one of the students to lead the prayer before starting the lesson. b, I checked the students' attendance, c. I asked the students about the topic and taught reading by applying the Cooperative Script Method, d. I ordered the students to form the pair work and read the text, e. I gave the test to evaluated their reading comprehension in Cycle 1

\section{c. Observing}

Observing was the way to know how the process of the treatment in teaching learning process by applying the Cooperative Script Method in teaching learning process, the students' achievement, the situation of the class, and their problem in reading.

d. Reflecting 
Based on the stage previously, I reflected the result of observing that has been carried out. It was as an evaluation of the students' reading improvement. In this stage, I tried to figure out if the students' reading comprehension has improved or it has not improved. Furthermore, I also tried to find out the students' difficulty in reading. Then, the result of this stage would be repaired in the Cycle 2. It intended to make an improvement of students' reading comprehension. If the Cycle 2 showed an improvement of the students' reading achievement, it means that I did not need for conducting the next cycle.

\section{DATA ANALYSIS AND DISCUSSION}

\subsection{The Data Analysis}

This research was conducted at SMP Negeri 21 Medan. This school uses KTSP 2006 (Kurikulum Tingkat Satuan Pendidkan). The materials of teaching are matched with KTSP 2006. The purpose of this research is to describe how the Cooperative Script Method could improve students' reading comprehension and to find out how good the second grade students of SMP Negeri 21 Medan are in reading comprehension after having been taught through the Cooperative Script Method.

\subsection{Discussion}

The general research question concerned in the improvement of students' reading comprehension in descriptive text after being applied Cooperative Script. The result showed there was in ways identifying a descriptive text can improve the students through Cooperative Script. The students identify the descriptive text about generic structure and language feature.

During applying this method, the activities in cycle 1 did not run smoothly. In cycle one, the students got confused about the procedure of method. The students still became passive learners, only some of them who following the part actively in the activities. In cycle II, the students showed good improvement in the activities and their comprehension on descriptive text. This method was considered successful in this research. It was not only shown from the process of activities, but also their comprehension test. In process students more active in asked and answered questions from me, students brought dictionary, and some students applied the Cooperative Script when did the individual test.

Based on the result of analyzing the data, it could be seen that the mean score of the Pretest was 39 and the mean score of the Posttest was 71. There was the difference of the results of the data. The situation of the class also was more actively and not boring since the students participated in learning process. It could be concluded that students; reading comprehension improved after the applying the Cooperative Script Method at the second grade students Class VIII-2 of SMP Negeri 21 Medan.

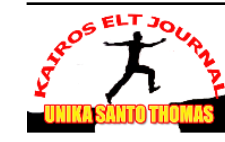




\section{CONCLUSION AND SUGGESTION}

\subsection{Conclusion}

having we conducted the research at the Eighth grade students Class VIII-2 of SMP Negeri 21 Medan, we conclude: (1) The students' reading comprehension is improved after applying Cooperative Script Method at the Eighth Grade students Class VIII-2 of SMP Negeri 21 Medan. It can be seen from the results of the data by the improvement of the students' mean score from the Pretest 39 to Posttest 71. It can be seen from the percentage of the students score $\geq 60$ which is $7 \%$ in Pretest and $65 \%$ in Posttest. It can be concluded that there is a significant mean score improvement between Pretest and Posttest about 58\%. It proved that the Cooperative Script Method can improve students' reading comprehension. Besides, Cooperative Script Method can be used to improve students reading comprehension and Cooperative Script Method can be a suggestion as a method in teaching reading to the students in Junior High School. (2) The result of the diary notes, interview, observation by applying the Cooperative Script Method makes the students active and the class situation is not boring since the students participate in teaching learning process by asking and answering the questions in turn.

\subsection{Suggestion}

With the research at the Eighth Grade students Class VIII-2 of SMP Negeri 21 Medan, it is suggested: (1) The Cooperative Script Method should be made as the alternative method for teaching reading skill to the students. The teachers need to investigate the students' attitudes in order to give them feedback in learning process. (2) The readers should improve their reading comprehension in order to avoid the problem and decrease the difficulties in comprehending the English language. (3) The students should study hard and improve their reading skill due to the reasons that most of scientific books nowadays are written in English Language. (4) There will be other researchers who are interested in conducting further research related to the Cooperative Script Method in improving the students' reading comprehension.

\section{BIBLIOGRAPHY}

Al, Talal. Abd., \& Hameed, Al. Odwan. The Effect of the Directed Reading Thinking Activity Jordan. International Journal of Humanities and Social Science, 2(16). 2012.

Adreson, Neil. "What is Reading? "In Nunan, D. (3rd Ed). Practical English Language Reaching. New York: Mc Graw Hill. 2003

Brown, Douglas. Teaching by principles: an interactive approach to language pedagogy. Englewood Cliffs, New Jersey: Prentice Hall Regents. 2004.

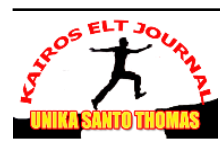


- Language Assessment Principles and Classroom Practices. White plains, NY: Pearson Education. 2003.

Burns, C.P, Roe. D. P and Ross, B.E. Reaching Reading in Today's Elementary Schools. Boston: Houghton Miffin Company. 1991.

Eileen,Ferance. Action Research. Northeast and Island Regional Educational Laboratory. Brown University. 2000.

Gerot, Linda., \& Peter Wignell. Making Sense of Functional Grammar. Gerd stabler :Sydney. 1994.

Grabe,William. \& Fredrika,L.Stoller. Teaching and Researching Reading. Harlow:Longman. 2002 , William and Fredrika L.S. Teaching and Researching Reading. Harlow:Longman. 2002

Nurul, Hidayah. Improving Students' Ability in Comprehending A Descriptive Text Through Cooperative Script. A Thesis, Unpublished. Tanjungpura University in Pontianak. 2015

Tampubolon, Saur. Penelitian Tindakan Kelas Sebagai Pengembangan Profesi Pendidik dan Keilmuan. Jakarta.Penerbit Erlangga. 2004.

Suprijono, Agus. Cooperative Learning: Teori \& Aplikasi Paikem. Yogyakarta: Pustaka Belajar. 2012.

Vanderstoep Scott W.,\& Jhonston Deirdre D. Research Method. Library of Congress Cataloging in-Publication Data. United States of America. 2009.

Wulandari, Sri. Improving Students' Reading Comprehension in Descriptive Text Through Cooperative Script Method at the eighth grade of SMP PGRI Slahung Ponogoro in Academic Year 2011/2012. A Thesis, Unpublished. Muhammadiyah University Ponogoro. 2012 